\title{
Investigating EFL Learners' Ability in Generating, Organizing, and Elaborating Ideas in an Argumentative Essay
}

\author{
M. Fadhly Farhy Abbas ${ }^{[1]}$, Herdi ${ }^{[2]}$ \\ Universitas Lancang Kuning \\ ${ }^{[1]}$ e-mail: fadhly@unilak.ac.id \\ [2] e-mail: herdi@unilak.ac.id
}

\begin{abstract}
This study aims at investigating EFL learners' ability in generating, organizing, and elaborating ideas of argumentative essay. Quantitative method with descriptive quantitative design was employed in this study. To collect the data, the writing test and unstructured interview were used in this research. This research was conducted on April 2018 at Universitas Lancang Kuning, Pekanbaru. There were 46 learners selected as participants in this research. The result of the writing test showed that the learners' mean score was 64.6 and it was categorized into low level of ability. Moreover, based on the interview the learners said that they felt difficult in elaborating ideas as well as organize the ideas in a good order. It was beacuse the learners had low alertness and carefulness in writing, low motivation to write an essay, low confidence when writing, and seldom to practice writing at leisure time. Therefore, appropriate writing strategy supported by suitable learning media is needed to facilitate and improve the learners' ability in writing the essay. In conclusion, the learners' ability in generating, organizing, and elaborating ideas is in low level of ability.
\end{abstract}

Keywords: EFL learners, Writing mechanics, Argumentative essay

\section{Investigasi Kemampuan Siswa EFL dalam Menggenerasikan, Menyusun, dan Mengelaborasi Ide dalam Esai Argumentatif}

\begin{abstract}
Abstrak
Penelitian ini bertujuan untuk menyelidiki kemampuan siswa $E F L$ dalam menggenerasikan, menyusun, dan mengelaborasi ide pada esai argumentatif. Metode kuantitatif dengan desain kuantitatif deskriptif digunakan dalam penelitian ini. Untuk mengumpulkan data, tes tertulis dan wawancara tidak terstruktur digunakan dalam penelitian ini. Penelitian ini dilakukan pada April 2018 di Universitas Lancang Kuning, Pekanbaru. Ada 46 peserta yang dipilih sebagai peserta dalam penelitian ini. Hasil tes menulis menunjukkan bahwa nilai rata-rata siswa adalah 64,6 dan dikategorikan ke dalam tingkat kemampuan yang lemah. Selain itu, berdasarkan wawancara, para siswa mengatakan bahwa mereka merasa sulit dalam mengelaborasi ide-ide serta menyusun ide-ide dalam urutan yang baik. Hal ini terjadi karena siswa memiliki kewaspadaan dan ketelitian yang rendah dalam menulis, motivasi rendah untuk menulis esai, kepercayaan diri rendah ketika menulis, dan jarang berlatih menulis di waktu senggang. Oleh karena itu, strategi penulisan yang tepat didukung oleh media pembelajaran yang sesuai diperlukan untuk memfasilitasi dan meningkatkan kemampuan siswa dalam
\end{abstract}


menulis esai. Kesimpulannya, kemampuan siswa dalam menggenerasikan, menyusun, dan mengelaborasi ide berada dalam tingkat kemampuan yang lemah.

Kata kunci: Siswa EFL, Mekanika penulisan, esai Argumentati

\section{INTRODUCTION}

Writing is one of the language skills that should be mastered by English Foreign Language (EFL) learners in university level, especially in English Study Program Faculty of Teachers Training and Education University of Lancang Kuning Pekanbaru. This is because the learners' achievement in writing can be used as a valuable contribution towards the development of English Language Teaching (ELT) in Indonesia, especially in the teaching of writing skill.

One of the writing skills that should be mastered by the students is writing an essay correctly. The better ability the students have in writing an essay, the better ability they have in writing another form of writing such as; academic writing, scientifc writing, argumentative essay, or various English text types.

In writing, there are two aspects that should be considered. First, writing process such as: prewriting, drafting, revising, editing, and publishing (Fachrurrazy, 2011: 90). Second, micro and macro skills of writing such as correct use of diction, grammar, and mechanics such as capitalization, punctuation, and spelling (Brown, 2007: 90). By considering those aspects of writing, writing activity will be easy and enable good improvement.

In line with those aspects, there are two another elements that should be existed in a composition.
These two elements are unity and coherence. Oshima and Hogue (2006: 18) state that unity is single idea in a paragraph and coherence is the relationship between one sentence to another or one paragraph to another. So, good paragraph or essay should be developed by good unity and coherence.

Pertaining to the statement above, generating and organizing ideas in an essay are really important to be done by the writers in their composition. By having good idea generation and organization, the writing or composition will become good and perfect. However, most the EFL learners especially the learners in English Departement of Universitas Lancang Kuning sometimes able to generate ideas but difficult to organize and elaborate the ideas to become good essay. It is happened because many factors that influenced it.

In accordance with those statements, the researchers interested in conducting a research in order to investigate the learners' ability in generating, organizing, and elaborating ideas in an argumentative essay and the factors that influence the learners' ability about it. Moreover, the result of this research can give clear description of the students' ability in writing an essay, especially in generating and organizing ideas in an argumentative essay. In addition, the result of this research can be used as an evaluation of writing course to improve the 
quality of the teaching of writing skill.

The research question of this study can be formulated as follows:

a. How is the learners' ability in generating, organizing, and elaborating ideas in an Argumentative essay?

b. What factors that influence the learners' ability in generating and organizing ideas in an Argumentative essay?

This study aims at investigating the learners' ability in generating, organizing, and elaborating ideas in an argumentative essay, and exploring the factors that influence the learners' ability in generating, organizing, and elaborating ideas in an argumentative essay.

It is also expected to be useful especially for: the learners, the teachers, and future researchers.

a. Learners

The learners can get a reflection of their ability in writing an essay.

b. Lecturers

The lecturers can get clear description of the learners' ability in generating and organizing ideas in an argumentative essay.

c. Future researchers

The references used in this study can be used by the next researchers to conduct further research.

\section{REVIEW OF LITERATURE}

In writing, there are many kinds of composition that can be produced such as paragraph and essay. Paragraph consist of several sentences explaining the topic (Hornby: 2010). Paragraph is also a group of related sentences which develop main idea of the topic. In a paragraph, there are three structures that can be written in a paragraph. The three structures of paragraph are: topic sentence, supporting sentence, and concluding sentence (Oshima and Hogue, 2006: 3-4). So, a good paragraph is a paragraph which contains the three structures of paragraph.

Meanwhile, essay is a group of paragraph which explains the subject or certain idea (Hornby:2010). In addition, good paragraph and essay should consist of Unity and Coherence. Oshima and Hogue (2006: 18) state that unity is single idea in a paragraph. Meanwhile coherence means idea in one sentence to another or one paragraph or another is hold together. So, a good paragraph or essay should contains good unity and coherence.

In relation to the previous explanation, there are some aspects that should be considered in writing paragraph and essay. Those aspects are: Content, Organization, Vocabulary, Grammar, Mechanics (Brown, 2007: 90). As a result, by considering those aspects, the paragraph and essay will be well composed.

In this part, the researchers highlighted some previous research which relevant to this research in order to support the theories used in 
this research. The relevant researches are as follow.

1. The research conducted by Abbas (2017) about assessing and evaluating EFL learners' ability in writing academic essay. After conducting the research, it was found that the learners' ability in writing academic essay was low. It was basically influenced by the diffulties in using correct grammar, diction and applying correct mechanics in their writing such as: puctuation, capitalization, and spelling.

2. The research done by Abbas (2015) about analysis of students' ability in writing a research proposal. From the finding, it can be identified that the students' difficulties in writing the research proposal was basically influenced by the students' difficulty in using correct grammar and writing mechanics: spelling, punctuation, and capitalization.

3. The research done by Gupta and Woldemariam (2011) about the influence of motivation and attitude toward writing strategy. From this research, it can be explained that the students with high motivation in writing can be viewed from high level of interest in writing, confident, good ability, and good attitude toward writing strategy. This result showed that, in order to be able to write composition well, it needs good motivation and high level of confident supported by good attitude and thought.

4. The research conducted by Hasan and Akhand (2010) about approaches to Writing in EFL/ESL Context: Balancing
Product and Process in Writing Class at Tertiary Level. From the finding, it can be indicated that collaborating both writing product and process could make the students to become outperform in the class. Of course all writing aspects including writing mechanics was applied correctly in the students' writing.

5. The research done by Crossley, Kyle, Varner, and McNamara (2014) about "The Importance of Grammar and Mechanics in Writing Assessment and Instruction: Evidence from Data Mining". Based on the findings, it was showed that there was weak relations between grammar errors and holistic essay scores and stronger relations between mechanics and holistic essay scores.

6. The research investigated by Faraj (2015) about "Scaffolding EFL Students' Writing through the Writing Process Approach". This research finding showed that the result that students' achievement in post-test compare to pre-test revealed significant improvement. Also, scaffolding students' writings through writing process approach met the students' needs in EFL writing, and then it has improved their writing skill, while most of them have had difficultly in the basic elements of writing, e.g. grammar. In addition, learners could more confidentially express their ideas in their writings.

7. The research investigated by Dabbagh (2017) about "The Effect of Dialogue Journal Writing on EFL Learners' Descriptive Writing Performance: 
A Quantitative Study". The findings proved that the results of independent sample $t$-test located a significant difference between the experimental and control group regarding the overall writing performance, as well as the sub-components of content, organization, and vocabulary in the post-test. However, the obtained results did not reveal a significant effect of dialogue journal writing on language use and mechanics of writing performance.

\section{METHOD}

The research design used in this study was descriptive quantitative. In this study, the researchers analyzed the data quantitatively by using scoring rubric. Then, the researcher described data descriptively. Moreover, the procedures of this research are as follow.

1. The researchers prepared the writing test for the learners.

2. The researchers analyzed the learners' ability in generating, organizing, and elaborating ideas.

3. The researchers interviewed the students to get additional information about the factors that influenced the learners' ability.

4. The researchers concluded the learners' ability in generating and organizing ideas.

The setting of this study was at English Education Department Faculty of Teachers Training and Education University of Lancang Kuning Pekanbaru, Riau Province, Indonesia.
The participants of this study were 46 learners. Moreover, the detail information about participants of this research can be seen at the Table 3.1.

Table 2.1 The Participants of the Study

\begin{tabular}{|c|c|c|}
\hline No & Grade & Learners \\
\hline 1 & IV A & 23 \\
\hline 2 & IV B & 23 \\
\hline \multicolumn{2}{|c|}{ Total } & 46 learners \\
\hline
\end{tabular}

In this research, the researcher collected the data by using test. The test used was writing an argumentative essay. Then, the students were asked to write an essay for about 5 paragraphs (500 words) in 90 minutes length. After that, the researcher interviewed the students to gain additional information about students' ability in writing an essay, especially in generating, organizing, and elaborating ideas.

The data which has been collected through the test was analyzed by using scoring rubric of essay writing. Then, the result of students' interview was analyzed descriptively. Moreover, the scoring rubric can be seen in the table below.

Table 2.2 The Scoring Rubric

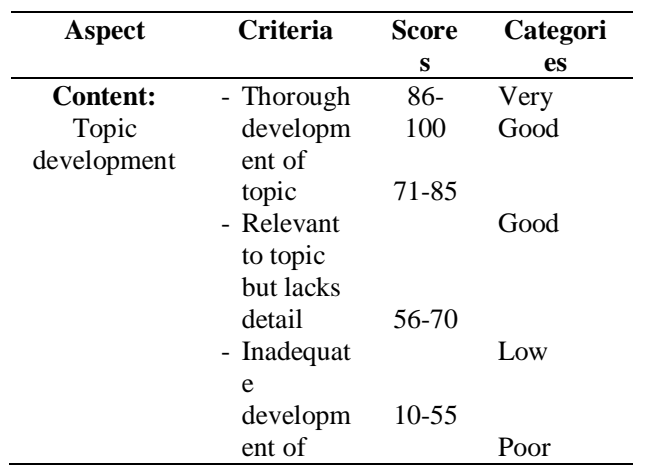

Investigating EFL Learners' Ability in Generating, Organizing, and Elaborating Ideas in an Argumentative Essay 


\begin{tabular}{|c|c|c|c|}
\hline & $\begin{array}{l}\text { topic } \\
\text { - Does not } \\
\text { show } \\
\text { knowledg } \\
\text { e of topic }\end{array}$ & & \\
\hline $\begin{array}{l}\text { Organizatio } \\
\text { n: } \\
\text { Structure and } \\
\text { paragraphing }\end{array}$ & $\begin{array}{l}\text { - Follow } \\
\text { the } \\
\text { structures } \\
\text { correctly } \\
\text { - Loosely } \\
\text { organized } \\
\text { but ideas } \\
\text { stand out } \\
\text { - Incoheren } \\
\text { t ideas } \\
\text { and lacks } \\
\text { logical } \\
\text { sequencin } \\
\text { g } \\
\text { - Does not } \\
\text { follow } \\
\text { the } \\
\text { structures } \\
\text { correctly }\end{array}$ & $\begin{array}{c}86- \\
100 \\
71-85\end{array}$ & $\begin{array}{l}\text { Very } \\
\text { Good } \\
\text { Good }\end{array}$ \\
\hline
\end{tabular}

(Adapted from Abbas: 2015)

\section{FINDING AND DISCUSSION}

In accordance with the data gained in this study, it can be stated that the learners' score in writing an argumentative essay was categorized into low level. It was because the learners' mean score was 64.6. For further information, the learners' score obtained from the test can be seen at the Table 4.1 below.

Table 3.1 The Learners' Score

\begin{tabular}{cccc}
\hline No & $\begin{array}{c}\text { Obtained } \\
\text { Score }\end{array}$ & $\begin{array}{c}\text { Score } \\
\text { category }\end{array}$ & $\begin{array}{c}\text { Number of } \\
\text { students }\end{array}$ \\
\hline 1 & $80-82$ & Very Good & 5 \\
2 & $72-79$ & Good & 12 \\
3 & $57-69$ & Fair & 18 \\
4 & $47-55$ & Poor & 11 \\
\hline
\end{tabular}

In addition, the data from the Table 3.1 can also be presented in the Diagram 3.1 below.

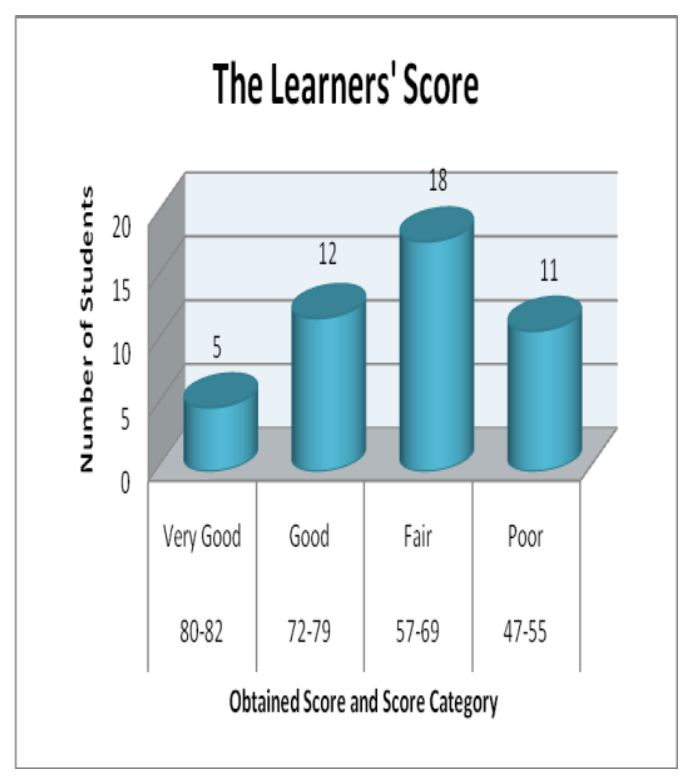

\section{Diagram 3.1 The Learners' Score}

From the Diagram above, it can be identified that 5 learners achieved very good score category with the score range 80-82, then 12 learners obtained good score category with the score range $72-79$, 18 learners got fair score category with the score range 57-69, and 11 learners got poor score category with the score range 47-55.

In accordance with the data obtained from the test, based on the result of interview, it can be explained that the learners difficulties in generating and organizing ideas in an argumentative essay were basically influenced by the alertness and the capability to write carefully in the essay. Mostly, the learners need to finish their writing as soon as possible, and it made them to become not alert with their writing especially in terms of generating, organizing, even in elaborating ideas. Therefore, appropriate writing strategy supported by suitable learning 
meadia is needed to facilitate and improve the learners' ability in writing the essay. This thing is in line with the research done by Hasan and Akhand (2010), Crossley, Kyle, Varner, and McNamara (2014), Faraj (2015), and Dabbagh (2017) about the importance of grammar, mechanics, and the approripate strategy of writing activity.

In relation to the previous statement, the students difficulties in applying writing mechanics were basically influenced by 3 factors such as: low motivation to write an essay, low confidence when writing, and seldom to practice writing at leisure time. This is in line with the research done by Gupta and Woldemariam (2011) about motivation and confidence toward writing a composition.

\section{CONCLUSION}

Based on the research findings, it can be concluded that the learners' score in writing an essay is categorized into low level score category. This is because the learners' mean score is 64.6. In addition, it can be stated that the students' achievement in generating, organizing, and elaborating ideas in an argumentative essay is influenced by several difficulties and factors such as: the students alertness and carefulness in writing, low motivation to write an essay, low confidence when writing, and seldom to practice writing at leisure time.

From this result, the students' difficulties or problems in generating, organizing, and elaborating ideas can be solved by considering appropriate or effective writing strategy. Therefore, it is suggested to future researchers to follow-up this research to become classroom action research or experimental research design as one of the solutions to overcome the students' problem in writing the essay or to see how effective the strategy in the teaching of writing.

\section{REFERENCES}

Abbas, M. Fadhly Farhy. "Assessing and Evaluating EFL Learners' Ability in Writing Academic Essay." Proceedings of ISELT FBS Universitas Negeri Padang 5 (2017): 257-261.

Abbas, M. Fadhly Farhy. 2015. Analysis of Students' Ability in Writing a Research Proposal, 44-47.

Arikunto, Suharsimi. 2010. Prosedur Penelitian Suatu Pendekatan Praktik: Edisi Revisi. Jakarta: Rineka Cipta.

Brown, H.D. 2007. Teaching by Principles; an Interactive Approach to Language Pedagogy (3 ${ }^{\text {rd }}$ Edition). White Plains, New York: Pearson Education.

Crossley, Kyle, Varner, and McNamara. 2014. The Importance of Grammar and Mechanics in Writing Assessment and Instruction: Evidence from Data Mining. Proceedings of the $7^{\text {th }}$ International Conference on Educational Data Mining, 
Institute of Education, London.

Dabbagh, Ali. 2017. The Effect of Dialogue Journal Writing on EFL Learners' Descriptive Writing Performance: A Quantitative Study. International Journal of Applied Linguistics \& English Literature, Vol. 6 No. 3; May 2017, Australian International Academic Centre.

Fachrurrazy. 2011. Teaching English as a Foreign Language for Teachers in Indonesia. Malang: Universitas Negeri Malang Press.

Faraj, Avan Kamal Aziz. 2015. Scaffolding EFL Students, Writing through the Writing Process Approach. Journal of Education and Practice Vol.6, No.13, 2015.

Gupta, Deepti \& Woldemariam G.S. 2011. The Influence of Motivation and Attitude on Writing Strategy Use of Undergraduate EFL Students: Quantitative and Qualitative Perspectives. Asian EFL Journal, Volume 13, Issue 2, 34-89

Hasan, Md Kamrul \& Akhand, Mohd. Moniruzzaman. 2010. Approaches to Writing in EFL/ESL Context: Balancing Product and Process in Writing Class at Tertiary Level.
Journal of NELTA Vol. 15 No. 1-2 December 2010.

Hornby. A.S. 2010. Oxford Advanced Learner's Dictionary ( $8^{\text {th }}$ edition). Cambridge: Longman.

Oshima, Alice \& Hogue, Ann. 2006. Writing Academic English (4th edition). New York: Pearson Longman. 
Appendix: The Result of the Test

\begin{tabular}{|c|c|c|c|}
\hline No & Students & Scores & Category \\
\hline 1 & Student 1 & 47 & Poor \\
\hline 2 & Student 2 & 52 & Low \\
\hline 3 & Student 3 & 57 & Low \\
\hline 4 & Student 4 & 65 & Low \\
\hline 5 & Student 5 & 57 & Low \\
\hline 6 & Student 6 & 57 & Low \\
\hline 7 & Student 7 & 60 & Low \\
\hline 8 & Student 8 & 62 & Low \\
\hline 9 & Student 9 & 62 & Low \\
\hline 10 & Student 10 & 52 & Poor \\
\hline 11 & Student 11 & 60 & Low \\
\hline 12 & Student 12 & 47 & Poor \\
\hline 13 & Student 13 & 52 & Poor \\
\hline 14 & Student 14 & 47 & Poor \\
\hline 15 & Student 15 & 52 & Poor \\
\hline 16 & Student 16 & 57 & Low \\
\hline 17 & Student 17 & 60 & Low \\
\hline 18 & Student 18 & 47 & Poor \\
\hline 19 & Student 19 & 57 & Low \\
\hline 20 & Student 20 & 47 & Poor \\
\hline 21 & Student 21 & 55 & Poor \\
\hline 22 & Student 22 & 57 & Low \\
\hline 23 & Student 23 & 55 & Poor \\
\hline
\end{tabular}

\begin{tabular}{|c|c|c|c|}
\hline 24 & Student 24 & 72 & Good \\
\hline No & Students & Scores & Category \\
\hline 25 & Student 25 & 74 & Good \\
\hline 26 & Student 26 & 69 & Low \\
\hline 27 & Student 27 & 82 & Very Good \\
\hline 28 & Student 28 & 80 & Very Good \\
\hline 29 & Student 29 & 69 & Low \\
\hline 30 & Student 30 & 74 & Good \\
\hline 31 & Student 31 & 72 & Good \\
\hline 32 & Student 32 & 79 & Good \\
\hline 33 & Student 33 & 67 & Low \\
\hline 34 & Student 34 & 62 & Low \\
\hline 35 & Student 35 & 79 & Good \\
\hline 36 & Student 36 & 79 & Good \\
\hline 37 & Student 37 & 67 & Low \\
\hline 38 & Student 38 & 69 & Low \\
\hline 39 & Student 39 & 77 & Good \\
\hline 40 & Student 40 & 77 & Good \\
\hline 41 & Student 41 & 80 & Very Good \\
\hline 42 & Student 42 & 72 & Good \\
\hline 43 & Student 43 & 74 & Good \\
\hline 44 & Student 44 & 74 & Good \\
\hline 45 & Student 45 & 82 & Very Good \\
\hline 46 & Student 46 & 80 & Very Good \\
\hline \multicolumn{2}{|c|}{ Mean score } & \multicolumn{2}{|c|}{64.6 (Low) } \\
\hline
\end{tabular}

